\title{
Impact on the environment and on human health of internal combustion, hybrid and battery electric powered vehicles in a life cycle perspective
}

\author{
Francesco Di Maria ${ }^{1,}$, Daniela Cesari $^{2}$, and Federico Sisani ${ }^{1}$ \\ ${ }^{1}$ DI Dipartimento di Ingegneria, University od Perugia, via G. Duranti 93, 06125 Perugia, Italy \\ ${ }^{2}$ ISAC CNR, Istituto di Scienze dell'Atmosfera e del Clima CNR UOS di Lecce, S.P. Lecce- \\ Monteroni km 1.2, 73100 Lecce, Italy
}

\begin{abstract}
Different power trained passenger cars were compared in a life cycle perspective (LCA) considering the Italian context for the year 2019. Main findings shows that battery electric vehicles, based on the current Italian energy mix, have the lower global warming emissions about 0.1 $\mathrm{kgCO}_{2 \mathrm{eq}} / \mathrm{km}$. Lower particulate emissions of about $5 \times 10^{-4} \mathrm{kgPM}_{2,5 \mathrm{eq}} / \mathrm{km}$ and impact on human health about $7 \times 10^{-7} / \mathrm{km}$ DALY were detected for petrol hybrid electric vehicles. Lower photochemical emissions of about $5 \times 10-4 \mathrm{kgNMVOC}_{\mathrm{eq}} / \mathrm{km}$ were found for gasoline internal combustion engines vehicles.
\end{abstract}

\section{Introduction}

Road transport still remain one of the most critical source of airborne emissions affecting the quality of urban environments and human health. According to [1] this sector contributes to about $39 \%$ to $80 \%$ for NOx and about $11 \%$ for PM emissions. Further restrictions to be implemented by upcoming Euro 7 standard is currently driving the automotive industry to replace the fossil and/or renewable fueled vehicles with hybrid and battery electric powered ones.

This transition will affect several aspects and in particular the environmental one, posing a strong debate about the effective sustainability of this transition [2-4].

Life cycle assessment approach (LCA) results largely adopted in literature for investigating the environmental and human health consequences due to different scenarios and system. In previous LCA studies [5] investigated the different impacts due to diesel fueled and battery electric vehicles (BEV) in Italy reporting that BEV had lower impacts concerning the amount of $\mathrm{kgCO}_{2 \mathrm{ca}}$ and $\mathrm{kgSO}_{2 \mathrm{c}}$ emitted but higher impacts concerning the

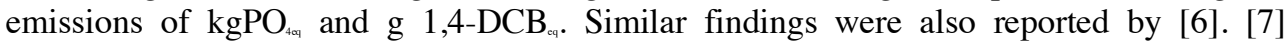
reported that $\mathrm{BEV}$ had lower emission of $\mathrm{kgCO} 2_{\text {с }}$ and $\mathrm{kgCFC} 11_{\text {ฯ }}$ compared fossil fuelled ones. Higher greenhouses emissions related to the primary energy demand (MJ), for different powered cars, were detected by [8] concerning BEV. For the impact on human health, nowadays there is a growing interest toward new indicators aimed to quantify the potential effects induced by air pollutants. Particular focus was PM emissions and the related effects on human health. Although the toxic effects of PM were already correlated with some chemical and physical properties [9-10], the toxicity mechanisms are not yet fully known. Some studies [11-13] suggested that several adverse health effects could be associated to the oxidative potential (OP) of PM, which leads to high concentrations of reactive oxygen species (ROS), chemical species capable of causing damage at the cellular

* Corresponding author: francesco.dimaria@unipg.it 
level. For this reason, the OP of atmospheric particulate has started to be considered as a general indicator of risks for human health associated to PM.

Based on this evidence the present study aims to compare in a LCA perspective the environmental impact of different power trained cars (e.g. gasoline, diesel, hybrid and $\mathrm{BEV})$ related to the Italian context. Furthermore, a literature review was also carried out about the latest studies reporting about the evidence of the correlations detected between $\mathrm{OP}$ and PMs generated by traffic.

\section{Material and methods}

The present study was conducted with particular reference to the Italian context considering cars homologate according to standard $\geq$ Euro 6 . For this reason, data used in the study were retrieved from literature, official reports and other technical documents concerning the specific area and/or areas with equivalent legal regulation and technological implementation in terms of cars emission and environmental legislation (i.e. EU27 and North America).

\subsection{The Euro 6 Italian passenger car fleet}

Table 1 reports the consistency of the Italian Euro 6 passenger cars. Table 2 reports the geometric mean $(\mu \mathrm{g})$ and the variance $(\sigma 2)$ related to the amount $(\mathrm{kg})$ of regulated pollutants emitted in exhaust per $\mathrm{km}$ driven by the different car sizes and powertrains. Table 3 report the non-exhaust PM emissions due to break and tyre abrasion [14-19]. The reduction of emissions due to regenerative break systems for BEV, PHEV and Petrol-HEV were also considered [20]. The amount of fuel consumed ranges from about $0.027 \mathrm{~kg} / \mathrm{km}$ for small size PHEV to $0.092 \mathrm{~kg} / \mathrm{km}$ for large size ICEVg whereas the electrical energy consumed ranged from about $0.04 \mathrm{kWh} / \mathrm{km}$ for small size PHEV to about $0.175 \mathrm{kWh} / \mathrm{km}$ for large size $\mathrm{BEV}$. The yearly mileage ranges from about $1.1 \mathrm{E}+4$ to about $2.0 \mathrm{E}+4$ for all the different sizes and powertrains and the larger share, from about $48 \%$ up to $68 \%$ resulted driven in rural areas. The share of mileage driven in urban area and highway ranged from about $15 \%$ to about $30 \%$ and from about $8 \%$ to about $32 \%$, respectively.

Table 1. Number of different powertrain and size Italian passenger cars homologate according to Euro 6 standard.

\begin{tabular}{|c|c|c|c|c|}
\hline Powertrain & Size & $\begin{array}{l}\text { Average } \\
\text { weight (kg) }\end{array}$ & Euro 6 IT fleet & References \\
\hline \multirow{3}{*}{ BEV } & Small & 1200 & & \multirow{14}{*}{ [21-25] } \\
\hline & Medium & 1600 & $22,627^{(a)}$ & \\
\hline & Large & 1800 & & \\
\hline \multirow{3}{*}{ PHEV } & Small & 1500 & 275 & \\
\hline & Medium & 1700 & 4,956 & \\
\hline & Large & 2300 & 8,536 & \\
\hline \multirow{3}{*}{ Petrol-HEV } & Small & 1100 & 23,626 & \\
\hline & Medium & 1400 & 196,738 & \\
\hline & Large & 1700 & 32,461 & \\
\hline \multirow{2}{*}{ Diesel-HEV $^{(b)}$} & Medium & - & 5,932 & \\
\hline & Large & - & 5,927 & \\
\hline \multirow{3}{*}{ ICEVg } & Small & 1200 & 298,1750 & \\
\hline & Medium & 1600 & 33,0127 & \\
\hline & Large & 2000 & 38881 & \\
\hline
\end{tabular}




\begin{tabular}{|l|l|l|l|l|}
\hline \multirow{3}{*}{ ICEVd } & Small & 1200 & 464978 & \multirow{2}{*}{} \\
\cline { 2 - 4 } & Medium & 1600 & 3671357 \\
\cline { 2 - 4 } & Large & 2000 & 373631 \\
\hline
\end{tabular}

Legend: $\mathrm{a}=$ global;

Table 2. Geometric mean $\left(\mathrm{m}_{\mathrm{g}}\right)$ and variance $\left(\sigma^{2}\right)$ of the emissions measured from Euro 6 passenger cars.

\begin{tabular}{|c|c|c|c|c|c|c|c|}
\hline \multirow[b]{2}{*}{ Powertrain } & \multirow[b]{2}{*}{ Size } & \multicolumn{5}{|c|}{ Regulated pollutants $(\mathrm{kg} / \mathrm{km})$} & References \\
\hline & & $\begin{array}{l}\mathrm{CO} \\
\left(\mu_{\mathrm{g}} / \sigma^{2}\right)\end{array}$ & $\begin{array}{l}\text { NOx } \\
\left(\mu_{\mathrm{g}} / \sigma^{2}\right)\end{array}$ & $\begin{array}{l}\text { PM } \\
\left(\mu_{\mathrm{g}} / \sigma^{2}\right)\end{array}$ & $\begin{array}{l}\text { THC } \\
\left(\mu_{\mathrm{g}} / \sigma^{2}\right)\end{array}$ & $\begin{array}{l}\text { PN } \\
\left(\mu_{\mathrm{g}} / \sigma^{2}\right)\end{array}$ & \\
\hline \multirow{3}{*}{ PHEV } & Small & $\begin{array}{l}3.80 \mathrm{e}- \\
4 / 7.32\end{array}$ & $\begin{array}{l}1.17 \mathrm{e}- \\
5 / 10.7\end{array}$ & $\begin{array}{l}6.71 \mathrm{e}- \\
7 / 4.99\end{array}$ & $\begin{array}{l}2.97 \mathrm{e}- \\
5 / 6.51\end{array}$ & $1.50 \mathrm{e} 12 / 4.54$ & \multirow{3}{*}[26-30]{} \\
\hline & Medium & $\begin{array}{l}1.76 \mathrm{e}- \\
3 / 1.94 \\
\end{array}$ & $\begin{array}{l}2.00 \mathrm{e}- \\
5 / 3.66\end{array}$ & $\begin{array}{l}6.12 \mathrm{e}- \\
7 / 3.93 \\
\end{array}$ & $\begin{array}{l}1.69 \mathrm{e}- \\
5 / 2.10\end{array}$ & $1.50 \mathrm{e} 12 / 2.60$ & \\
\hline & Large & $\begin{array}{l}3.03 \mathrm{e}- \\
5 / 51.7\end{array}$ & $\begin{array}{l}5.82 \mathrm{e}- \\
5 / 3.21\end{array}$ & $\begin{array}{l}7.51 \mathrm{e}- \\
7 / 71.5\end{array}$ & $\begin{array}{l}1.30 \mathrm{e}- \\
6 / 94.5\end{array}$ & $2.30 \mathrm{e} 12 / 10.2$ & \\
\hline \multirow{3}{*}{ Petrol-HEV } & Small & $\begin{array}{l}4.62 \mathrm{e}- \\
4 / 7.08 \\
\end{array}$ & $\begin{array}{l}9.67 \mathrm{e}- \\
6 / 5.08 \\
\end{array}$ & $\begin{array}{l}1.48 \mathrm{e}- \\
6 / 1.03 \\
\end{array}$ & $\begin{array}{l}4.18 \mathrm{e}- \\
5 / 8.70\end{array}$ & $2.57 \mathrm{e} 12 / 1.46$ & \multirow{3}{*}[26,28;31-34]{} \\
\hline & Medium & $\begin{array}{l}8.25 \mathrm{e}- \\
5 / 7.18 \\
\end{array}$ & $\begin{array}{l}1.00 \mathrm{e}- \\
5 / 17.1\end{array}$ & $\begin{array}{l}3.30 \mathrm{e}- \\
7 / 3.65\end{array}$ & $\begin{array}{l}9.49 \mathrm{e}- \\
6 / 19.3 \\
\end{array}$ & $2.00 \mathrm{e} 11 / 7.25$ & \\
\hline & Large & $\begin{array}{l}1.67 \mathrm{e}- \\
4 / 4.43\end{array}$ & $\begin{array}{l}1.40 \mathrm{e}- \\
5 / 8.63\end{array}$ & $\begin{array}{l}1.18 \mathrm{e}- \\
6 / 5.76\end{array}$ & $\begin{array}{l}1.00 \mathrm{e}- \\
6 / 30.1\end{array}$ & $2.30 \mathrm{e} 12 / 4.78$ & \\
\hline \multirow{3}{*}{ ICEVg } & Small & $\begin{array}{l}5.33 e- \\
4 / 15.3\end{array}$ & $\begin{array}{l}1.70 \mathrm{e}- \\
5 / 28.3\end{array}$ & $\begin{array}{l}6.00 \mathrm{e}- \\
7 / 9.16\end{array}$ & $\begin{array}{l}5.00 \mathrm{e}- \\
6 / 36.5\end{array}$ & $1.63 \mathrm{e} 11 / 27.4$ & \multirow{3}{*}[26,32;34-9]{} \\
\hline & Medium & $\begin{array}{l}1.55 \mathrm{e}- \\
4 / 11.5\end{array}$ & $\begin{array}{l}8.70 \mathrm{e}- \\
6 / 6.50\end{array}$ & $\begin{array}{l}5.00 \mathrm{e}- \\
7 / 74.7\end{array}$ & $\begin{array}{l}1.69 \mathrm{e}- \\
5 / 87.4\end{array}$ & $2.16 \mathrm{e} 11 / 81.1$ & \\
\hline & Large & $\begin{array}{l}2.23 \mathrm{e}- \\
4 / 4.50\end{array}$ & $\begin{array}{l}1.42 \mathrm{e}- \\
5 / 8.34\end{array}$ & $\begin{array}{l}6.75 \mathrm{e}- \\
7 / 5.15\end{array}$ & $\begin{array}{l}1.35 \mathrm{e}- \\
6 / 116\end{array}$ & $1.06 \mathrm{e} 12 / 4.74$ & \\
\hline \multirow{3}{*}{ ICEVd } & Small & $\begin{array}{l}3.00 \mathrm{e}- \\
5 / 18.3 \\
\end{array}$ & $\begin{array}{l}1.19 \mathrm{e}- \\
4 / 15.5 \\
\end{array}$ & $\begin{array}{l}6.00 \mathrm{e}- \\
7 / 787 \\
\end{array}$ & $\begin{array}{l}4.00 \mathrm{e}- \\
6 / 20.6 \\
\end{array}$ & $3.50 \mathrm{e} 10 / 138$ & \multirow{3}{*}[30,32,35,38,40,41]{} \\
\hline & Medium & $\begin{array}{l}3.10 \mathrm{e}- \\
5 / 23.8\end{array}$ & $\begin{array}{l}3.16 \mathrm{e}- \\
4 / 13.4\end{array}$ & $\begin{array}{l}2.00 \mathrm{e}- \\
7 / 67.5\end{array}$ & $\begin{array}{l}1.25 \mathrm{e}- \\
5 / 5.91\end{array}$ & $4.90 \mathrm{e} 9 / 70.0$ & \\
\hline & Large & $\begin{array}{l}1.56 \mathrm{e}- \\
4 / 21.6\end{array}$ & $\begin{array}{l}3.11 \mathrm{e}- \\
4 / 8.96 \mathrm{E} 4\end{array}$ & $\begin{array}{l}4.42 \mathrm{e}- \\
7 / 11.1\end{array}$ & $\begin{array}{l}3.95 \mathrm{e}- \\
5 / 8.81\end{array}$ & $1.28 \mathrm{e} 11 / 22.6$ & \\
\hline
\end{tabular}

Table 3. Geometric mean $\left(\mu_{\mathrm{g}}\right)$ and variance $\left(\sigma^{2}\right)$ of $\mathrm{kg}$ of different classes of PM emitted per km driven from brake and tyre abrasion for different car sizes and power trains.

\begin{tabular}{|c|c|c|c|c|c|c|c|}
\hline \multirow[t]{3}{*}{ Powertrain } & \multirow[t]{3}{*}{ Size } & \multicolumn{3}{|c|}{ Brake non-exhaust $\left(\mu_{\mathrm{g}} / \sigma^{2}\right)$} & \multicolumn{3}{|c|}{ Tyre non-exhaust $\left(\mu_{\mathrm{g}} / \sigma^{2}\right)$} \\
\hline & & \multicolumn{3}{|c|}{$(\mathrm{kg} / \mathrm{km})$} & \multicolumn{3}{|c|}{$(\mathrm{kg} / \mathbf{k m})$} \\
\hline & & $\mathrm{PM}<2.5$ & $2.5<\mathrm{PM}<10$ & $\mathrm{PM}>10$ & $\mathrm{PM}<2.5$ & $2.5<\mathrm{PM}<10$ & $\mathrm{PM}>10$ \\
\hline \multirow{3}{*}{$\mathrm{BEV}$} & Small & $\begin{array}{l}4.17 \mathrm{E}- \\
7 / 1.52 \\
\end{array}$ & $6.30 \mathrm{E}-7 / 1.52$ & $\begin{array}{l}2.14 \mathrm{E}- \\
/ 1.52\end{array}$ & $\begin{array}{l}3.44 \mathrm{E}- \\
/ 1.52\end{array}$ & $1.47 \mathrm{E}-6 / 1.52$ & $\begin{array}{l}3.26 \mathrm{E}- \\
6 / 1.52\end{array}$ \\
\hline & Medium & $\begin{array}{l}5.55 \mathrm{E}- \\
7 / 1.52\end{array}$ & $8.40 \mathrm{E}-7 / 1.52$ & $\begin{array}{l}2.85 \mathrm{E}- \\
/ 1.52\end{array}$ & $\begin{array}{l}4.58 \mathrm{E}- \\
/ 1.52\end{array}$ & $1.96 \mathrm{E}-6 / 1.52$ & $\begin{array}{l}4.35 \mathrm{E}- \\
6 / 1.52\end{array}$ \\
\hline & Large & $\begin{array}{l}6.25 \mathrm{E}- \\
7 / 1.52\end{array}$ & $9.45 \mathrm{E}-7 / 1.52$ & $\begin{array}{l}3.20 \mathrm{E}- \\
/ 1.52\end{array}$ & $\begin{array}{l}5.16 \mathrm{E}- \\
/ 1.52\end{array}$ & $2.21 \mathrm{E}-6 / 1.52$ & $\begin{array}{l}4.89 \mathrm{E}- \\
6 / 1.52\end{array}$ \\
\hline \multirow{2}{*}{ PHEV } & Small & $\begin{array}{l}5.21 \mathrm{E}- \\
7 / 1.55\end{array}$ & $7.88 \mathrm{E}-7 / 1.55$ & $\begin{array}{l}2.67 \mathrm{E}- \\
11.55\end{array}$ & $\begin{array}{l}\text { 4.30E- } \\
/ 1.55\end{array}$ & $1.84 \mathrm{E}-6 / 1.55$ & $\begin{array}{l}4.07 \mathrm{E}- \\
6 / 1.55\end{array}$ \\
\hline & Medium & $\begin{array}{l}5.90 \mathrm{E}- \\
7 / 1.55\end{array}$ & $8.93 \mathrm{E}-7 / 1.55$ & $\begin{array}{l}3.03 \mathrm{E}- \\
/ 1.55\end{array}$ & $\begin{array}{l}4.87 \mathrm{E}- \\
/ 1.55\end{array}$ & $2.08 \mathrm{E}-6 / 1.55$ & $\begin{array}{l}4.62 \mathrm{E}- \\
6 / 1.55\end{array}$ \\
\hline
\end{tabular}




\begin{tabular}{|c|c|c|c|c|c|c|c|}
\hline & Large & $\begin{array}{l}7.98 \mathrm{E}- \\
7 / 1.55\end{array}$ & $1.21 \mathrm{E}-6 / 1.55$ & $\begin{array}{l}4.09 \mathrm{E}- \\
/ 1.55\end{array}$ & $\begin{array}{l}6.59 \mathrm{E}- \\
/ 1.55\end{array}$ & $2.82 \mathrm{E}-6 / 1.55$ & $\begin{array}{l}6.25 \mathrm{E}- \\
6 / 1.55\end{array}$ \\
\hline \multirow{3}{*}{ Petrol-HEV } & Small & $\begin{array}{l}3.82 \mathrm{E}- \\
7 / 1.55\end{array}$ & $5.78 \mathrm{E}-7 / 1.52$ & $\begin{array}{l}1.96 \mathrm{E}- \\
/ 1.55\end{array}$ & $\begin{array}{l}3.15 \mathrm{E}- \\
/ 1.55\end{array}$ & $1.35 \mathrm{E}-6 / 1.55$ & $\begin{array}{l}2.99 \mathrm{E}- \\
6 / 1.55\end{array}$ \\
\hline & Medium & $\begin{array}{l}4.86 \mathrm{E}- \\
7 / 1.55\end{array}$ & $7.35 \mathrm{E}^{-7} / 1.55$ & $\begin{array}{l}2.49 \mathrm{E}- \\
/ 1.55\end{array}$ & $\begin{array}{l}4.01 \mathrm{E}- \\
/ 1.55\end{array}$ & $1.72 \mathrm{E}-6 / 1.55$ & $\begin{array}{l}3.80 \mathrm{E}- \\
6 / 1.55\end{array}$ \\
\hline & Large & $\begin{array}{l}5.90 \mathrm{E}- \\
7 / 1.52\end{array}$ & $8.93 \mathrm{E}^{-7} / 1.55$ & $\begin{array}{l}3.03 \mathrm{E}- \\
/ 1.55\end{array}$ & $\begin{array}{l}4.87 \mathrm{E}- \\
/ 1.55\end{array}$ & $2.08 \mathrm{E}-6 / 1.55$ & $\begin{array}{l}4.62 \mathrm{E}- \\
6 / 1.55\end{array}$ \\
\hline \multirow{3}{*}{ ICEVg } & Small & $\begin{array}{l}1.97 \mathrm{E}- \\
6 / 1.63\end{array}$ & $3.40 \mathrm{E}-6 / 1.63$ & $\begin{array}{l}1.28 \mathrm{E}- \\
/ 1.63\end{array}$ & $\begin{array}{l}3.71 \mathrm{E}- \\
/ 1.61\end{array}$ & $1.59 \mathrm{E}-6 / 1.61$ & $\begin{array}{l}3.91 \mathrm{E}- \\
6 / 1.61 \\
\end{array}$ \\
\hline & Medium & $\begin{array}{l}2.58 \mathrm{E}- \\
6 / 1.63\end{array}$ & $4.45 \mathrm{E}-6 / 1.63$ & $\begin{array}{l}1.68 \mathrm{E}- \\
/ 1.63\end{array}$ & $\begin{array}{l}4.86 \mathrm{E}- \\
/ 1.61\end{array}$ & $2.08 \mathrm{E}-6 / 1.61$ & $\begin{array}{l}5.12 \mathrm{E}- \\
6 / 1.61\end{array}$ \\
\hline & Large & $\begin{array}{l}3.20 \mathrm{E}- \\
6 / 1.63\end{array}$ & $5.52 \mathrm{E}-6 / 1.52$ & $\begin{array}{l}2.08 \mathrm{E}- \\
/ 1.63\end{array}$ & $\begin{array}{l}5.98 \mathrm{E}- \\
/ 1.61\end{array}$ & $2.56 \mathrm{E}-6 / 1.61$ & $\begin{array}{l}6.30 \mathrm{E}- \\
6 / 1.61\end{array}$ \\
\hline \multirow{3}{*}{ ICEVd } & Small & $\begin{array}{l}1.97 \mathrm{E}- \\
6 / 1.63\end{array}$ & $3.40 \mathrm{E}-6 / 1.63$ & $\begin{array}{l}1.28 \mathrm{E}- \\
/ 1.63\end{array}$ & $\begin{array}{l}3.71 \mathrm{E}- \\
/ 1.61\end{array}$ & $1.59 \mathrm{E}-6 / 1.61$ & $\begin{array}{l}3.91 \mathrm{E}- \\
6 / 1.61\end{array}$ \\
\hline & Medium & $\begin{array}{l}2.58 \mathrm{E}- \\
6 / 1.63\end{array}$ & $4.45 \mathrm{E}-6 / 1.63$ & $\begin{array}{l}1.68 \mathrm{E}- \\
11.63\end{array}$ & $\begin{array}{l}4.86 \mathrm{E}- \\
/ 1.61\end{array}$ & $2.08 \mathrm{E}-6 / 1.61$ & $\begin{array}{l}5.12 \mathrm{E}- \\
6 / 1.61 \\
\end{array}$ \\
\hline & Large & $\begin{array}{l}3.20 \mathrm{E}- \\
6 / 1.63\end{array}$ & $5.52 \mathrm{E}-6 / 1.52$ & $\begin{array}{l}2.08 \mathrm{E}- \\
11.63\end{array}$ & $\begin{array}{l}5.98 \mathrm{E}- \\
/ 1.61\end{array}$ & $2.56 \mathrm{E}-6 / 1.61$ & $\begin{array}{l}6.30 \mathrm{E}- \\
6 / 1.61\end{array}$ \\
\hline
\end{tabular}

\subsection{The Life Cycle Assessment}

\subsection{Goal, scope and functional unit}

The LCA was developed according to the ISO [42-44]. Calculations were performed by SimaPro 8.5.2.

The goal was to assess environmental and human health impacts associated to direct and indirect emissions from Italian passenger cars in the year 2019 respecting standard not lower than Euro 6 one [32,45]. Powertrains considered were: plug-in hybrid electrical vehicles (PHEV); petrol hybrid vehicles (petrol-HEV); gasoline internal combustion engines (ICEVg); petrol internal combustion engines (ICEVp); BEV. Three main size groups, depending on their average weight (i.e. small, medium, large) were identified (Table 1).

Powertrain fueled by compressed/liquid natural gas and liquefied petroleum gas were not included in the study. Main backgrounds were represented by fuel, energy, materials and chemicals necessary for the construction, use and maintenance of the vehicles (Fig. 1). Main foregrounds were represented by emissions due to tyre and brake abrasion and by exhaust emission for those vehicles powered by internal combustion engines. The end of life of the vehicles and of their components were assumed to be practically the same for all the different power train systems considered and for this reason not included in the present study. The functional unit chosen was the distance of $1 \mathrm{~km}$ driven that was also assumed as reference unit. 


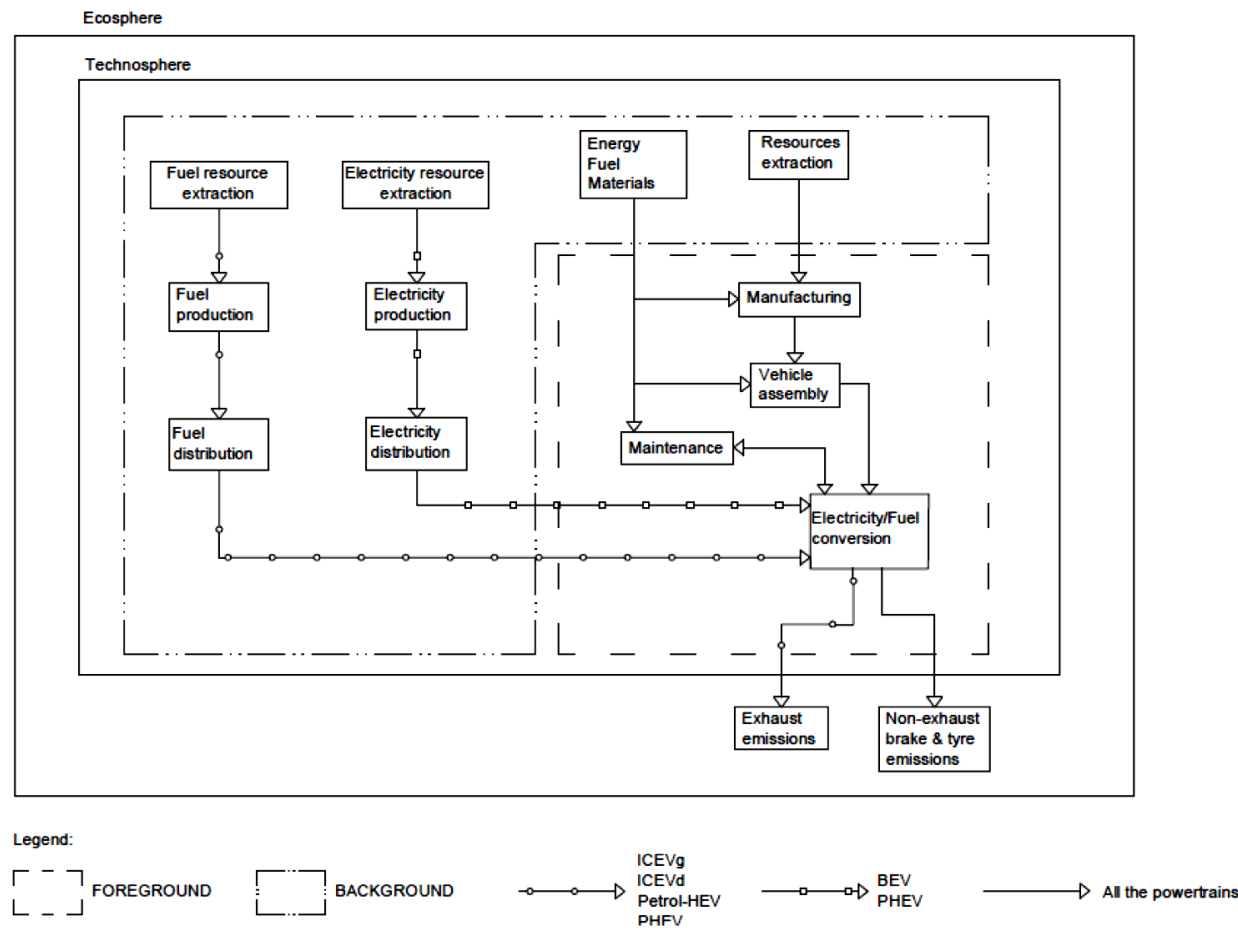

Fig. 1. Systems boundaries for (a) battery electric vehicles (BEV), (b) plug-in hybrid electric vehicle (PHEV), (c) petrol and diesel hybrid vehicles (petrol-HEV; diesel-HEV), (d) patrol and diesel internal combustion engines (ICEVg; ICEVp).

Table 4. Midpoint and Endpoint impact indicators.

\begin{tabular}{|l|l|}
\hline Impact category & Unit \\
\hline Environmental Midpoint ILCD 2011+ & \\
\hline Global warming potential - GWP & $\mathrm{kg} \mathrm{CO}_{2} \mathrm{eq}$ \\
\hline Photochemical Ozone Formation - POF & $\mathrm{kg} \mathrm{NMVOC}_{\mathrm{eq}}$ \\
\hline Particulate matter - PM & $\mathrm{kg} \mathrm{PM}_{2.5} \mathrm{eq}$ \\
\hline Resource Depletion - RD & $\mathrm{kg} \mathrm{Sbeq}$ \\
\hline Human health Endpoint IMPACT 2000+ & \\
\hline Human health - HH & DALY \\
\hline
\end{tabular}

\subsection{Impact indicators and assessment method}

Environmental and health consequences were assessed by using both mid and end point impact indicators (Table 4). Midpoint indicators used for the assessment of the environmental consequences were: global warming (GWP) $\left(\mathrm{kgCO}_{2 \mathrm{ca}}\right)$; particulate matter (PM) $\left(\mathrm{kgPM}_{2 \mathrm{sen}_{4}}\right)$; photochemical ozone formation (POF) $\left(\mathrm{kgNMVOC}_{\mathrm{cs}}\right)$; resource depletion (RD) $\left(\mathrm{kgSb}_{\mathrm{a}}\right)$. For the assessment of the consequences on human health the end point human health (HH) (DALY) was adopted.

Midpoint indicators were quantified by the ILCD 2011+ assessment method [46] whereas the endpoint indicator HH was quantified by the IMPACT 2000+ assessment method [47]. 


\subsection{Oxidative Potential and cars PM emission}

The OP of fine aerosol $\left(\mathrm{PM}_{25}\right)$ has been widely applied to evaluate both its oxidation ability and its impact on health [48] and can be quantified by measuring the dithiothreitol (DTT) consumption rate (nmoli/min*m) of particulate matter, with DTT serving as a substitute for cellular reductants [49]. Since the DTT consumption rate is considered to be influenced by the chemical composition of $\mathrm{PM}_{25}$ (e.g. organics, metals, inorganics, carbonaceous, elemental and metallic species) several studies investigate the corelation between the DTT consumption rate and $\mathrm{PM}_{25}$ chemical compounds.

Various studies have reported the significant correlation between DTT and different chemical components of particulate matter in the atmosphere, including humic-like substances, water soluble organic compounds (WSOC) and water soluble transition metals (WSTM) [50-52]. However, it is worth to highlight that the contributions of respective PM sources to its oxidative potential remain largely unresolved because of the complex interactions among chemicals that are DTT-active.

Considering traffic emissions, the DTT activity could be related to many pollutants produced by this source. We must say that "traffic" is a source category influenced by different kinds of emissions deriving from many different vehicle types and related processes [53]. In addition to the primary PM emissions from exhaust and the emissions of organic and inorganic gaseous PM precursors from the combustion of fuel and lubricant, vehicles emit significant amounts of particles through the wear of brake linings, clutch, and tyres. These are deposited onto the road and subsequently re-suspended by vehicle traffic together with crustal/mineral dust particles and road wear material. Source apportionment studies reported in literature showed traffic source profiles containing elemental carbon (EC), Fe, $\mathrm{Ba}, \mathrm{Zn}, \mathrm{Cu}$ and $\mathrm{Pb}$ (Viana et al., 2008b) with hopanes and steranes, that can be used in receptor models (RMs) for distinguishing exhaust from gasoline and diesel powered engines, together with the certain OC fractions [54]. Metals such as $\mathrm{Cu}, \mathrm{Zn}, \mathrm{Mn}, \mathrm{Sb}, \mathrm{Sn}$, $\mathrm{Mo}, \mathrm{Ba}$, and $\mathrm{Fe}$ are markers of brake wear and can serve as indicators of traffic resuspension $[55,56]$. Some of these cited chemical species are well correlated with DTT activity. For example, in [50] and [51] and in [52] strong positive correlations between DTT activity and OC, EC, and water-soluble transition metals were showed. Further, in table 5 some studies on oxidative potential of PM are reported as example, where DTT values (normalized per volume, $\mathrm{nm} / \mathrm{min}^{*} \mathrm{~m}^{3}$ ) and the PM component potentially inducing PM oxidative potential are indicated.

A recent study [57] reported that, for $\mathrm{PM}_{25}$ fraction, carbonaceous species, i.e. organic carbon (OC), elemental carbon (EC), WSOC, secondary organic carbon (SOC), and some of the measured metal elements such as $\mathrm{Cu}, \mathrm{Fe}, \mathrm{Mn}, \mathrm{Sr}, \mathrm{Mg}, \mathrm{Al}, \mathrm{Ti}, \mathrm{V}$ well correlate with the DTT activity. The source apportionment study present in this study showed that the mixed sources of traffic and road dust resuspension and coal combustion were the major sources of the oxidative potential of $\mathrm{PM}_{2 s}$ while the direct vehicle emission contributed the least to DTT activity.

In [51] it has been showed that the major drivers of DTT activity of fine PM are biomass burning and secondary aerosols, with their respective annual contributions of 35 and $31 \%$. This is followed by vehicle emissions contributing $16 \%$ annually, while road dust contributes minimally ( $9 \%$ ) to the DTT activity of $\mathrm{PM}_{2.5}$. Considering OP studies reported in literature, it is reasonable asserting that a transition from gasoline/diesel powered engines vehicle to electric engines could have an impact to exhaust emissions and on OP activity of urban aerosol according to the reduction of carbonaceous species emissions; otherwise, OP activity due to metals associated to not exhaust emissions (detectable in brake wear and road dust) should not change. Obviously, this assertion should be confirmed by dedicated sampling campaign to be performed in urban areas. Furthermore, the expected increase in 
electrical energy consumption due to the larger diffusion of BEV could lead to an increase of both gaseous emissions, including $\mathrm{PM}_{25}$, and fossil fuels consumption for power plants currently suppling $>65 \%$ of the whole Italian electricity needs.

Table 5. DTT $\left(\mathrm{nmol} / \mathrm{min}^{*} \mathrm{~m}^{3}\right.$ ) and the PM components potentially inducing PM oxidative potential. This kind of information has been obtained in all studies for whom the squared Pearson correlation coefficients $\left(R^{2}\right)$ between measured chemical species and the DTT assay response was $\geq 0.5$.

\begin{tabular}{|c|c|c|}
\hline PM components & $\begin{array}{c}\text { DTTv } \\
\left(\mathbf{n m o l} / \mathbf{m i n} \cdot \mathbf{m}^{3}\right)\end{array}$ & Reference \\
\hline $\begin{array}{c}\text { WSOC, } \mathrm{BrC}, \mathrm{SO}_{4^{2}}, \mathrm{NH}_{4^{+}}, \mathrm{EC}, \\
\mathrm{OC}, \mathrm{K}, \mathrm{Ca}, \mathrm{Mn}, \mathrm{Fe}, \mathrm{Cu}, \mathrm{Zn}\end{array}$ & $0.1-1.5$ & {$[51]$} \\
\hline $\mathrm{OC}, \mathrm{EC}, \mathrm{NO}_{3}, \mathrm{Ca}^{2+}$ & $0.19( \pm 0.10)$ & {$[58]$} \\
\hline black carbon, $\mathrm{NO}_{3}, \mathrm{NH}_{4^{+}}$ & $0.33( \pm 0.20)$ & [59] \\
\hline $\begin{array}{c}\text { OC, Polycyclic Aromatic } \\
\text { Hydrocarbons }\end{array}$ & $\begin{array}{c}0.23 \\
(0.11-0.34)\end{array}$ & {$[60]$} \\
\hline $\mathrm{Cu}, \mathrm{Zn}, \mathrm{Cr}, \mathrm{Fe}, \mathrm{Mn}$ & $0.3-1.7$ & [61] \\
\hline $\begin{array}{c}\mathrm{NO}_{3^{-}}, \mathrm{SO}_{4^{2-}} \mathrm{NH}_{4}^{+}, \mathrm{WSOC}, \mathrm{Mg}, \\
\mathrm{Al}, \mathrm{K}, \mathrm{Ti}, \mathrm{Fe}, \mathrm{PAHs}\end{array}$ & $0.62( \pm 0.21)$ & {$[62]$} \\
\hline
\end{tabular}

\section{Results and discussion}

Direct emissions from fuel combustion represents the main contribution to GWP (kgCO2eq) for ICEVd, ICEVg, petrol.HEV and PHEV (Fig. 2) whereas contributions to construction and fuel supply resulted significantly lower. Those associated to maintenance were practically marginal. BEV showed $\mathrm{kgCO}_{\text {rakm }}$ halved compared to previous cars with a large contribution to GWP of the electricity $(\mathrm{kWh} / \mathrm{km})$ consumed.

Large and medium ICEVg and both PHEB and BEV cars showed higher POF $(\mathrm{kgNMVOCeq} / \mathrm{km})$ emission.

For ICEVg the larger contributions to POF were represented by exhaust emissions and to fuel supply. Also in this case maintenance resulted negligible.

For both PHEV and BEV emissions of $\mathrm{kgNMVOCeq} / \mathrm{km}$ were largely influenced by the maintenance.

Lower average emissions of PM $(\mathrm{kgPM} 2,5 \mathrm{eq} / \mathrm{km})$ were detected for patrol-HEV and for medium and small ICEVd even if the higher standard deviation was detected for the PHEV Large and ICEVg Medium cars, respectively. In this case the larger average contributions to PM emissions were represented by fuel supply, by the non-exhaust (i.e. tyre and brake abrasion) and by the construction phase. BEV showed the higher average values of $\mathrm{kgPM} 2,5 \mathrm{eq} / \mathrm{km}$. In this case the most relevant contributions were, in order of importance: the electricity production; the construction; and the tyre non-exhaust. The incidence of brake non-exhaust resulted practically negligible due to the effect of the regenerative braking system (Table 3). Both PHEV and BEV showed the higher average FWE emissions $(\mathrm{kgPeq} / \mathrm{km})$ mainly due to the contribution of the electricity production whereas both large ICEVg and ICEVd showed the higher values for $\mathrm{A}\left(\mathrm{molcH}_{\mathrm{ta}} / \mathrm{km}\right)$. In this last case the main contribution was due to the fuel supply. BEV were charged by the higher average $(\mathrm{CTUe} / \mathrm{km})$ and RD $(\mathrm{kgSbeq} / \mathrm{km})$ emissions. Of particular interest appears the results that in a life cycle perspective the impact on human health (DALY) of BEV is practically 
similar to the one of ICEVg and that best performances (i.e. lower impact) were achieved by petrol-HEVadn small size ICEVd.

The amount of $\mathrm{kgCO} 2 \mathrm{eq}$ emitted from BEV, ICEVd and ICEVg reported in the study of [5] were in line with those reported in the present study. The same study reported also the $\mathrm{kmPM} 2,5$ emitted from these vehicles were practically the same whereas the emissions of $\mathrm{kgNMVOC}$ resulted lower for BEV and higher for ICEVg.

In another study [63] BEV resulted charged by the higher emission of $\mathrm{kgPM} 2,5 \mathrm{eq}$ and mol $\mathrm{H}+\mathrm{eq}$ compared to ICEVd and ICEVg.

In comparing ICEVg, HEV, PHEV and BEV [8] found higher GWP for the first power trained cars.

Even if the expected increase in electrical energy consumption due to the larger diffusion of $\mathrm{BEV}$ will probably increase of gaseous emissions and $\mathrm{PM}_{2,}$ from power plants, [58] found that high PM levels are not necessarily correlated to high OP activity since the influence of chemical composition. Figure 3 reports some correlations found in literature between DTT $\left(\mathrm{nmol} / \mathrm{min}^{*} \mathrm{~m}^{3}\right)$ and some different chemical compounds detected in PM.

This is another aspect worthy to be investigated for having a global picture of the impact on the environment and on human health related to the new private mobility paradigm. 

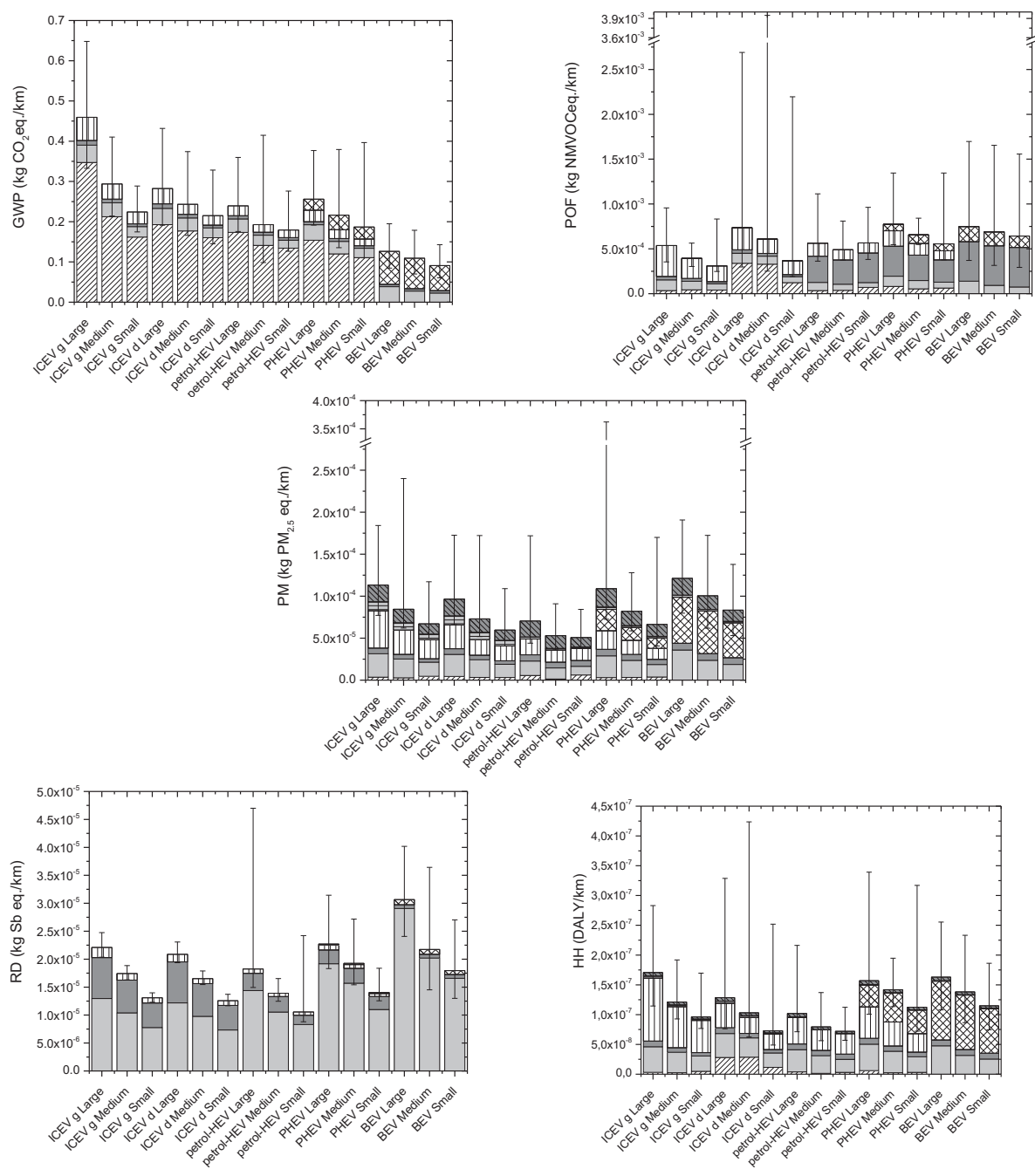

\section{Exhaust emissions} Brake Non-Exhaust
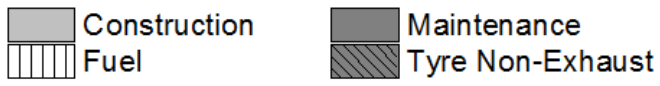

Fig. 2. Geometric mean and standard deviation of the characterization of the midpoint environmental impact indicators. 


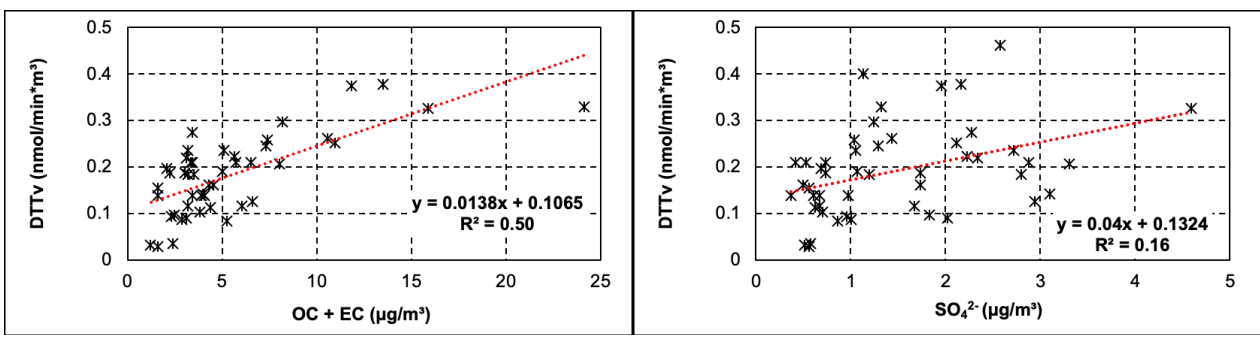

Fig. 3. Example of correlations between DTTv $\left(\mathrm{nmol} / \mathrm{min}^{*} \mathrm{~m}^{3}\right)$ and different chemical species (i.e. carbonaceous species and sulphate, $\mu \mathrm{g} / \mathrm{m}^{3}$ ) [58].

\section{Conclusions}

Based on the current Italian electricity mix, battery electric vehicles resulted credited by the lower greenhouses emission compared to both fossil fuelled and hybrid ones. Quite similar or in any case comparable emissions levels were found concerning particulate matter and resource depletion. The same results were also achieved concerning the consequence on human health for which petrol hybrid vehicles were credited by the lower impacts. What affects the current emission levels in particular of battery electric vehicles is represented by the ones associated to the construction phase, by particulate emissions due to tyres abrasion and by the electricity consumption. A particular care has to be pointed on this last aspect. In fact, since the larger diffusion of battery electric vehicles this could lead to an overall increase of the Italian electrical energy demand causing an increase of the amount of fossil fuel to be exploited in thermal power plants with possible increase of the overall impacts. Finally more research activity resulted necessary for a better understanding of the correlation between particulate emissions from the different activities considered and oxidative potential.

\section{References}

1. EEA. 2019. Air quality in Europe - 2019 report. ISBN 978-92-9480-088-6.

2. Biresselioglu, M.E., Kaplan, M.D., Yilmaz, B.K., 2018. Electric mobility in Europe: A comprehensive review of motivators and barriers in decision making processes. Transportation Research Part A 109,1-13.

3. Requia, W.J., Mohamed, M., Higgins, C.D., Araind, A., Fergusone, M. 2018. How clean are electric vehicles? Evidence-based review of the effects ofelectric mobility on air pollutants, greenhouse gas emissions and humanhealth. Atmospheric Environment 185,64-77.

4. Onata, N.C., Kucukvar, M., Aboushaqrah, N.N.M., Jabbara, R. 2019. How sustainable is electric mobility? A comprehensive sustainability assessment approach for the case of Qatar. Applied Energy 2019,461-477.

5. Girardi, P., Gargiulo, A., Brambilla, P.C., 2015. A comparative LCA of an electric vehicle and an internal combustion engine vehicle using the appropriate power mix: the Italian case study. Int J Life Cycle Assess 20:1127-1142.

6. Tagliaferri, C., Evangelisti, S., Acconcia, F., Domonech, T., Ekins, P., Barletta, D., Lettieri, P. 2016. Life cycle assessment of future electric and hybrid vehicles: A cradle- 
to-grave systems engineering approach. Chemical Engineeering Research and Design 112:298-309.

7. Helmers, E., Dietz, J., Weiss, M. 2020. Sensitivity Analysis in the Life-Cycle Assessment of Electric vs. Combustion Engine Cars under Approximate Real-World Conditions. Sustainability 12,1241.

8. Rosenfeld, D.C., Lindorfer, J., Fazeni-Fraisl, K. 2019. Comparison of advanced fuelsWhich technology can win from the life cycle perspective? Journal of Cleaner Production 238, 117879.

9. Di Maria, F., Mastrantonio, M., Uccelli, R., 2021. The life cycle approach for assessing the impact of municipal solid waste incineration on the environment and on human health. Science of the Total Environment 776,145785.

10. Kim, K.H., Kabir, E., Kabir, S., 2015. A review on the human health impact of airborne particulate matter. Environmental International 74,136-143.

11. Delfino, R.J., Staimer, N., Tjoa, T., Gillen, D.L., Schauer, J.J., Shafer, M.M., 2013. Airway inflammation and oxidative potential of air pollutant particles in a pediatric asthma panel. Journal of Exposure Analysis and Environmental Epidemiology 23, 466-473.

12. Li, N., Sioutas, C., Cho, A., Schmitz, D., Misra, C., Sempf, J., Wang, M., Oberley, T., Froines, J., Nel, A., 2003. Ultrafine particulate pollutants induce oxidative stress and mitochondrial damage. Environmental Health Perspective , 111, 455-460.

13. Li, N., Wang, M., Bramble, L.A., Schmitz, D.A., Schauer, J.J., Sioutas, C., Harkema, J.R., Nel, A.E., 2009. The adjuvant effect of ambient particulate matter is closely reflected by the particulate oxidant potential. Environmental Health Perspective, 117, 1116-1123.

14. Ntziachristos, L., Boulter, P., 2009. EMEP/EEA emission inventory guidebook 2009. Road vehicle tyre and brake wear-Road surface wear. Available at: https://www.eea.europa.eu/publications/emep-eea-emission-inventory-guidebook-2009

15. BUWAL, 2000. Swiss Agency for the Environment, Forests and Landscape Informationen zur Entsorgung von Altreifen. Available at: http://www.umweltschweiz.ch/buwal/de/fachgebiete/fg_abfall/abfallwegweiser/altpneu/index.html

16. Garg, B., Cadle, S., Mulawa, P., Groblicki, P., Laroo, C., Parr, G., 2000. Brake wear particulate matter emissions. Environ. Sci. Technol. 34 (21), 4463e4469. Available at: doi:10.1021/es001108h

17. Gibaek K. and Seokhwan L. (2018). Characteristics of Tire Wear Particles Generated by a Tire Simulator under Various Driving Conditions. Environ. Sci. Technol. 2018, 52, 12153-12161. doi: 10.1021/acs.est.8b03459

18. Timmers, V.R.J.H., Achten, P.A.J., 2016. Non-exhaust PM emissions from electric vehicles. Atmos. Environ. https://doi.org/10.1016/j.atmosenv.2016.03.017

19. Ferdinand H. Farwick zum Hagen, Marcel Mathissen, Tomasz Grabiec, Tim Hennicke, Marc Rettig, Jaroslaw Grochowicz, Rainer Vogt, Thorsten Benter (2019). On-road vehicle measurements of brake wear particle emissions. Atmospheric Environment 217, 116943. doi: 10.1016/j.atmosenv.2019.116943.

20. Del Duce, A., Gauch, M., Althaus, H.-J., 2016. Electric passenger car transport and passenger car life cycle inventories in ecoinvent version 3. Int J Life Cycle Assess 21:1314-1326. DOI 10.1007/s11367-014-0792-4

21. Simons, A., 2016. Road transport: new life cycle inventories for fossil-fuelled passenger cars and non-exhaust emissions in ecoinvent v3. Int. J. Life Cycle Assess. 21, 1299-1313. https://doi.org/10.1007/s11367-013-0642-9

22. ICCT., 2020. International Council on Clean Transportation - European Vehicle Market Statistics Pocketbook 2018/19. Available online at: http://eupocketbook.theicct.org. (accessed 25.04.2021) 
23. ICCT, 2021. European Vehicle Market Statistics Pocketbook 2019/20. Available online at: http://eupocketbook.theicct.org. (accessed 25.04.2021)

24. ACI., 2019. Italian Automobil Club - Self-portrait 2019-Statistical data on the Italian vehicle fleet consistency. Available at: http://www.aci.it/laci/studi-e-rICEVrche/dati-estatistiche/autoritratto/autoritratto-2019.html

25. ANFIA, 2020. Italian Association of the Automotive Industry - Studies and statistics. Available at: https://www.anfia.it/en/statistical-data

26. Sánchez, P.P.R., Ndiaye, A.B., Martín-Cejas, R.R., 2019. Plug-in hybrid electric vehicles (PHEVs): A possible perverse effect generated by environmental policies. Int. J. Transp. Dev. Integr. 3, 259-270. https://doi.org/10.2495/TDI-V3-N3-259-270

27. Ehrenberger, S.I., Konrad, M., Philipps, F., 2020. Pollutant emissions analysis of three plug-in hybrid electric vehicles using different modes of operation and driving conditions. Atmos. Environ. 234. https://doi.org/10.1016/j.atmosenv.2020.117612

28. Franco, V., Zacharopoulou, T., Hammer, J., Schmidt, H., Mock, P., Weiss, M., Samaras, Z., 2016. Evaluation of Exhaust Emissions from Three Diesel-Hybrid Cars and Simulation of After Treatment Systems for Ultralow Real-World NOx Emissions. Environ. Sci. Technol. 50, 13151-13159. https://doi.org/10.1021/acs.est.6b03585

29. Lijewski, P., Kozak, M., Fuć, P., Rymaniak, Ł., Ziółkowski, A., 2020. Exhaust emissions generated under actual operating conditions from a hybrid vehicle and an electric one fitted with a range extender. Transp. Res. Part D Transp. Environ. 78. https://doi.org/10.1016/j.trd.2019.11.012

30. Suarez-Bertoa, R., Pavlovic, J., Trentadue, G., Otura-Garcia, M., Tansini, A., Ciuffo, B., Astorga, C., 2019. Effect of Low Ambient Temperature on Emissions and Electric Range of Plug-In Hybrid Electric Vehicles. ACS Omega 4, 3159-3168. https://doi.org/10.1021/acsomega.8b02459

31. Suarez-Bertoa, R., Astorga, C., 2016. Unregulated emissions from light-duty hybrid $\begin{array}{lllll}\text { electric } & \text { vehicles. } & \text { Atmos. }\end{array}$ https://doi.org/10.1016/j.atmosenv.2016.04.021

32. ISPRA, 2020. Road Transport data 1990-2019. Available at: http://www.sinanet.isprambiente.it/it/sia-ispra/serie-storiche-emissioni/dati-trasportostradale/view

33. Mehsein, K., Norsic, C., Chaillou, C., Nicolle, A., 2020. Minimizing secondary pollutant formation through identification of most influential volatile emissions in gasoline exhausts: Impact of the vehicle powertrain technology. Atmos. Environ. 226. https://doi.org/10.1016/j.atmosenv.2020.117394

34. Huang, Y., Surawski, N.C., Organ, B., Zhou, J.L., Tang, O.H.H., Chan, E.F.C., 2019. Fuel consumption and emissions performance under real driving: Comparison between hybrid and conventional vehicles. Sci. Total Environ. 659, 275-282. https://doi.org/10.1016/j.scitotenv.2018.12.349

35. Suarez-Bertoa, R., Pechout, M., Vojtíšek, M., Astorga, C., 2020. Regulated and nonregulated emissions from euro 6 diesel, gasoline and CNG vehicles under real-world driving conditions. Atmosphere 11, 204. https://doi.org/10.3390/atmos11020204

36. Yang, Z., Liu, Y., Wu, L., Martinet, S., Zhang, Y., Andre, M., Mao, H., 2020. Realworld gaseous emission characteristics of Euro $6 \mathrm{~b}$ light-duty gasoline- and dieselfueled vehicles. Transp. Res. Part D Transp. Environ. 78, 102215. https://doi.org/10.1016/j.trd.2019.102215

37. Suarez-Bertoa, R., Mendoza-Villafuerte, P., Riccobono, F., Vojtisek, M., Pechout, M., Perujo, A., Astorga, C., 2017. On-road measurement of NH3 emissions from gasoline and diesel passenger cars during real world driving conditions. Atmos. Environ. 166, 488-497. https://doi.org/10.1016/j.atmosenv.2017.07.056 
38. Weber, C., Sundvor, I., Figenbaum, E., 2019. Comparison of regulated emission factors of Euro $6 \mathrm{LDV}$ in Nordic temperatures and cold start conditions: Diesel- and gasoline direct-injection. Atmos. Environ. 206, 208-217. https://doi.org/10.1016/j.atmosenv.2019.02.031

39. McCaffery, C., Zhu, H., Li, C., Durbin, T.D., Johnson, K.C., Jung, H., Brezny, R., Geller, M., Karavalakis, G., 2020. On-road gaseous and particulate emissions from GDI vehicles with and without gasoline particulate filters (GPFs) using portable emissions measurement systems (PEMS). Sci. Total Environ. 710. https://doi.org/10.1016/j.scitotenv.2019.136366

40. García-Contreras, R., Soriano, J.A., Fernández-Yáñez, P., Sánchez-Rodríguez, L., Mata, C., Gómez, A., Armas, O., Cárdenas, M.D., 2021. Impact of regulated pollutant emissions of Euro 6d-Temp light-duty diesel vehicles under real driving conditions. J. Clean. Prod. 286. https://doi.org/10.1016/j.jclepro.2020.124927

41. Valverde, V., Giechaskiel, B., 2020. Assessment of Gaseous and Particulate Emissions of a Euro 6d-Temp Diesel Vehicle Driven $>1300 \mathrm{~km}$ Including Six Diesel Particulate Filter Regenerations. Atmosphere 11, 645. https://doi.org/10.3390/atmos11060645

42. ISO 14040. 2006. Environmental Management: Life Cycle Assessment, Principles and Guidelines. International Organization of Standardization, Geneva, p. 2006.

43. ISO 14042. 2000. Environmental Management - Life Cycle Assessment - Life Cycle Impact Assessment. International Organization of Standardization, Geneva, p. 2000.

44. ISO 14044. 2018. Environmental Management: Life Cycle Assessment -Requirements and guidelines. International Organization of Standardization, Geneva, p. 2018.

45. ISPRA, 2019. Database of the Italian average road transport emission factors. Available at http://www.sinanet.isprambiente.it/it/sia-ispra/fetransp (accessed 22/04/2021).

46. EC. 2010b. European Commission - Joint Research Centre - Institute for Environment and Sustainability. 2010. International Reference Life Cycle Data System (ILCD) Handbook - General guide for Life Cycle Assessment - Detailed guidance. First edition EUR 24708 EN March 2010 Publications OffICEV of the European Union Luxembourg, LU.

47. Jolliet, O., Pennington, D., Amman, C., Pelichet, T., Margni, M. Crettaz, P., 2005. Comparative assessment of the toxic impact of metals on humans within IMPACT 2002. In: Dubreuil, A. (Ed.), Life Cycle Assessment of Metals - Issues and Research Directions. SETAC Press. ISBN 1-880611-62-7.

48. Crobeddu, B., Aragao-Santiago, L., Bui, L.C., Boland, S., Squiban, A.B., 2017. Oxidative potential of particulate matter (PM2.5) as predictive indicator of cellular stress. Environmental Pollution 230: 125-133.

49. Cho, A.K., Sioutas, C., Miguel, A.H., Kumagai, Y., Schmitz, D.A., Singh, M., et al., 2005. Redox activity of airborne particulate matter at different sites in the Los Angeles Basin. Environmental Research 99: 40-47.

50. Verma, V., Rico-Martinez, R., Kotra, N., King, L., Liu, J., Snell, T.W., et al., 2012. Contribution of water-soluble and insoluble components and their hydrophobic/hydrophilic sub-fractions to the reactive oxygen species-generating potential of fine ambient aerosols. Environmental Science \& Technology 46: 1138411392.

51. Verma, V., Fang, T., Guo, H., King, L., Bates, J.T., Peltier, R.E., et al., 2014. Reactive oxygen species associated with water-soluble PM2.5 in the southeastern United States: spatiotemporal trends and source apportionment. Atmospheric Chemistry and Physics 14: $12915-12930$. 
52. Chirizzi, D., Cesari, D., Guascito, M.R., Donateo, A., Contini, D., 2017. Influence of Saharan dust outbreaks and carbon content on oxidative potential of water-soluble fractions of PM2.5 and PM10. Atmospheric Environment, 163:1-8.

53. Belis, C.A., Karagulian, F., Larsen, B.R., Hopke, P.K., 2013. Critical review and metaanalysis of ambient particulate matter source apportionment using receptor models in Europe. Atmospheric Environment 69: 94-108

54. Watson, J.G., Chen, L.W.A., Chow, J.C., Doraiswamy, P., Lowenthal, D.H., 2008. Source apportionment: findings from the U.S. supersites program. Journal of the Air and Waste Management Association 58: 265-288

55. Amato, F., Nava, S., Lucarelli, F., Querol, X., Alastuey, A., Baldasano, J.M., Pandolfi,M., 2010. A comprehensive assessment of PM emissions from paved roads: real-world emission factors and intense street cleaning trials. Science of the Total Environment 408: 4309-4318.

56. Schauer, J.J., Lough, G.C., Shafer, M.M., Christensen, W.F., Arndt, M.F., DeMinter, J.T.,Park, J.-S., 2006. Characterization of Metals Emitted from Motor Vehicles. Health Effect Institute.

57. Ahmad, M., Yu, Q., Chen,J., Cheng, S., Qin, W., Zhang, Y., 2021. Chemical characteristics, oxidative potential, and sources of PM2.5 in wintertime in Lahore and Peshawar, Pakistan. Journal of Environmental Sciences 102: 148-158

58. Cesari, D. , Merico, E., Grasso, F.M., Decesari, S., Belosi, F., Manarini, F., De Nuntiis, P., Rinaldi, M., Volpi, F., Gambaro, A., Morabito, E., Contini, D., 2019. Source Apportionment of PM2.5 and of its Oxidative Potential in an Industrial Suburban Site in South Italy. Atmosphere 10: 758.

59. Paraskevopoulou, D., Bougiatioti, A., Stavroulas, I., Fang, T., Lianou, M., Liakakou, E., Gerasopoulos, E., Weber, R., Nenes, A., Mihalopoulos, N., 2019. Yearlong variability of oxidative potential of particulate matter in an urban Mediterranean environment. Atmospheric Environment 206: 183-196.

60. Jedynska, A., Hoek, G., Wang, M., Yang, A., Eeftens, M., Cyrys, J., Keuken, M., Ampe, C., Beelen, R., Cesaroni, G., et al., 2017. Spatial variations and development of land use regression models of oxidative potential in ten European study areas. Atmospheric Environment 150: 24-32.

61. Visentin, M., Pagnoni, A., Sarti, E., Pietrogrande, M.C., 2016. Urban PM2.5 oxidative potential: Importance of chemical species and comparison of two spectrophotometric cell-free assays. Environmental Pollution 219: 72-79.

62. Verma, V., Ning, Z., Cho, A.K., Schauer, J.J., Shafer, M.M., Sioutas, C., 2009. Redox activity of urban quasi-ultrafine particles from primary and secondary sources. Atmospheric Environment 43: 6360-6368.

63. Buoter, A., Hache, E., Ternal, C., Beauchet, S., 2020. Comparative environmental life cycle assessment of several powertrain types for cars and buses in France for two driving cycles: "worldwide harmonized light vehicle test procedure" cycle and urban cycle. Int J of Life Cycle Assess 25,1545-1564. 